\title{
Distribution of killer cell immunoglobulin-like receptors genes in the Italian Caucasian population
}

\author{
A Bontadini*1, M Testi ${ }^{2}, \mathrm{MC} \mathrm{Cuccia}^{3}, \mathrm{M} \mathrm{Martinetti}^{3}, \mathrm{C} \mathrm{Carcassi}^{3}, \mathrm{~A} \mathrm{Chiesa}^{3}$, \\ E Cosentini $^{3}$, E Dametto ${ }^{3}$, S Frison ${ }^{3}$, AM Iannone ${ }^{3}$, C Lombardo $^{3}$, \\ A Malagoli ${ }^{3}, \mathrm{M} \mathrm{Mariani}^{3}, \mathrm{~L} \mathrm{Mariotti}^{3}$, L Mascaretti ${ }^{3}, \mathrm{~L} \mathrm{Mele}^{3}, \mathrm{~V} \mathrm{Miotti}^{3}$, \\ S Nesci ${ }^{3}$, G Ozzella ${ }^{3}$, D Piancatelli ${ }^{3}$, G Romeo ${ }^{3}$, C Tagliaferri ${ }^{3}$, S Vatta ${ }^{3}$, \\ $\mathrm{M}$ Andreani ${ }^{2}$ and $\mathrm{R}$ Conte ${ }^{1}$
}

Address: ${ }^{1}$ Transfusion Service, S. Orsola-Malpighi Hospital, Bologna, Italy, ${ }^{2}$ Mediterranean Institute of Hematology, Rome, Italy and ${ }^{3}$ Italian KIR Collaborative AIBT Group, Italy

Email: A Bontadini* - immunogeneticasmt@aosp.bo.it; M Testi - m.testi@fondazioneime.org; MC Cuccia - immunogeneticasmt@aosp.bo.it; M Martinetti - immunogeneticasmt@aosp.bo.it; C Carcassi - immunogeneticasmt@aosp.bo.it; A Chiesa - immunogeneticasmt@aosp.bo.it; E Cosentini - immunogeneticasmt@aosp.bo.it; E Dametto - immunogeneticasmt@aosp.bo.it; S Frison - immunogeneticasmt@aosp.bo.it; AM Iannone - immunogeneticasmt@aosp.bo.it; C Lombardo - immunogeneticasmt@aosp.bo.it; A Malagoli - immunogeneticasmt@aosp.bo.it; M Mariani - immunogeneticasmt@aosp.bo.it; L Mariotti - immunogeneticasmt@aosp.bo.it; L Mascaretti - immunogeneticasmt@aosp.bo.it; L Mele - immunogeneticasmt@aosp.bo.it; V Miotti - immunogeneticasmt@aosp.bo.it; S Nesci - immunogeneticasmt@aosp.bo.it; G Ozzella - immunogeneticasmt@aosp.bo.it; D Piancatelli - immunogeneticasmt@aosp.bo.it; G Romeo - immunogeneticasmt@aosp.bo.it; C Tagliaferri - immunogeneticasmt@aosp.bo.it; S Vatta - immunogeneticasmt@aosp.bo.it; M Andreani - immunogeneticasmt@aosp.bo.it; R Conte - immunogeneticasmt@aosp.bo.it

* Corresponding author

Published: 27 October 2006

Journal of Translational Medicine 2006, 4:44 doi:10.1 I86/1479-5876-4-44

Received: 21 July 2006

Accepted: 27 October 2006

This article is available from: http://www.translational-medicine.com/content/4/I/44

(C) 2006 Bontadini et al; licensee BioMed Central Ltd.

This is an Open Access article distributed under the terms of the Creative Commons Attribution License (http://creativecommons.org/licenses/by/2.0), which permits unrestricted use, distribution, and reproduction in any medium, provided the original work is properly cited.

\begin{abstract}
Background: Killer cell immunoglobulin-like receptors (KIRs) are a family of inhibitory and activatory receptors that are expressed by most natural killer (NK) cells. The KIR gene family is polymorphic: genomic diversity is achieved through differences in gene content and allelic polymorphism. The number of KIR loci has been reported to vary among individuals, resulting in different KIR haplotypes. In this study we report the genotypic structure of KIRs in 2 I 7 unrelated healthy Italian individuals from 22 immunogenetics laboratories, located in the northern, central and southern regions of Italy.

Methods: Two hundred and seventeen DNA samples were studied by a low resolution PCR-SSP kit designed to identify all KIR genes.

Results: All 17 KIR genes were observed in the population with different frequencies than other Caucasian and nonCaucasian populations; framework genes KIR3DL3, KIR3DPI, KIR2DL4 and KIR3DL2 were present in all individuals. Sixtyfive different profiles were found in this Italian population study. Haplotype A remains the most prevalent and genotype $\mathrm{I}$, with a frequency of $\mathbf{2 8 . 5 \%}$, is the most commonly observed in the Italian population.

Conclusion: The Italian Caucasian population shows polymorphism of the KIR gene family like other Caucasian and nonCaucasian populations. Although 64 genotypes have been observed, genotype I remains the most frequent as already observed in other populations. Such knowledge of the KIR gene distribution in populations is very useful in the study of associations with diseases and in selection of donors for haploidentical bone marrow transplantation.
\end{abstract}




\section{Background}

Killer cell immunoglobulin-like receptors (KIRs) are glycoproteins expressed on the cell surface of natural killer (NK) and subsets of T cells. These polymorphic receptors interact with specific motifs on HLA class I molecules, modulate NK cytolytic activity and are encoded by genes located on chromosome 19q13.4 [1-3].

They have been divided into distinct groups, depending on the number of external immunoglobulin domains (2D or 3D). The presence of a long cytoplasmatic tail with two immune tyrosine-based inhibitory motifs (ITIMs) allows the transduction of inhibitory signals and characterizes the inhibitory KIRs (2DL, 3DL), whereas the presence of short cytoplasmatic tails corresponds to the activating KIR receptors (2DS, 3DS) [1-4].

Due to the functional link between HLA class I molecules, KIRs are expected to display a high polymorphism. Studies on KIR genes in different populations, along with HLA system evaluations, can provide valuable information about the history and geography of human genes, while a wide range of genotypes may be expected in the human populations [5-8].

Most KIR haplotypes belong to one of two broad groups, termed A and B. The haplotypes have a framework of three conserved blocks containing KIR3DL3, KIR2DL4 and KIR3DL2 and differ in the number and type of KIR genes. Group A haplotype has a unique combination of seven KIR genes, while B haplotype exhibits a substantial variability in KIR gene number. Both groups of genotypes have been found in all populations analysed so far, but their distribution varies considerably among ethnic groups $[5,9,10]$.

Several studies have associated KIR genes with disease susceptibility, immune responsiveness and events following allogenic transplantation; recent reports have implicated KIRs in affecting the outcome of hematopoietic stem-cell transplantation [11].

The aim of this multicentric study was to determine the percentage of the population positive for individual KIR genes and the genotype pattern in a representative ethnic Italian group of 217 samples, using a new low-resolution, gene-level KIR PCR-SSP typing; we compare the data so obtained with those previously described in other Caucasian and non-Caucasian populations

\section{Materials and methods}

217 unrelated healthy Italian individuals from $22 \mathrm{immu}-$ nogenetics laboratories located in northern, central and southern regions of Italy were randomly selected to represent a fair, representative ethnic Italian group.
Each laboratory typed 10 DNA samples. DNA was previously extracted from peripheral blood samples drawn in EDTA anticoagulant tubes by standard protocols (e.g. salting-out); the DNA concentration and the ratio were evaluated. All participating laboratories performed KIR typing using the same low resolution PCR-SSP assay and the same lot number (KIR Genotyping Kit, Dynal Biotech, Pel-Freez Clinical Systems, Brown Deer, WI, USA) following the manufacturer's instructions. The kit was designed to identify 14 KIR genes (2DL1, 2DL2, 3DL1, 2DL4, 2DL5, 2DS1, 2DS2, 2DS3, 2DS4, 2DS5, 3DL1, 3DL2, 3DL3, 3DS1), 2 pseudogenes (2DP1 and 3DP1) and the common variants of KIR2DL5 (KIR2DL5A, KIR2DL5B), the KIR2DS4 allele ( ${ }^{*} 001 / 002$ and $\left.{ }^{*} 003\right)$ and KIR3DP1 allele $\left({ }^{*} 001 / 002\right.$ and $\left.{ }^{*} 003\right)$.

The specificity of the assay was previously tested by all participating laboratories on a panel of two shared DNA chosen by two reference laboratories to cover the amplification of all mixes included in the typing kit.

PCR-SSP was performed following the manufacturer's instructions. Briefly, $25 \mu \mathrm{l}$ of DNA at a concentration of $75-125 \mathrm{ng} / \mu \mathrm{l}$ with ratio $>1.5$ was mixed with $150 \mu \mathrm{l}$ of PCR Buffer, $2.4 \mu \mathrm{l}$ of Taq polymerase and $85 \mu \mathrm{l}$ of distilled water. Eight $\mu$ l of this mixture was added to each mix except for the contamination control where a mixture without DNA was used.

Genomic polymerase chain reaction analysis was performed under the conditions recommended by the manufacturers: 1 minute at $95^{\circ} \mathrm{C}$ for one cycle followed by 30 cycles formed of 20 seconds at $94^{\circ} \mathrm{C}, 20$ seconds at $63^{\circ} \mathrm{C}$ and 90 seconds at $72^{\circ} \mathrm{C}$. At the end a constant temperature of $4^{\circ} \mathrm{C}$ was maintained.

PCR products was transferred to the well of a $2 \%$ agarose gel capable of resolving 50-2000 base pair fragments of DNA. The DNA separation was performed at 150 volts for 22-25 minutes. The amplification was checked on a UV transilluminator and photographed. The typing was interpreted by a worksheet.

Statistical analysis was performed as follows: the percentage of the population positive for KIR genes was determined by direct counting. Differences between populations were compared by $\chi^{2}$ and Yates-corrected $P$ values for the number of loci investigated.

Linkage disequilibrium $(\Delta)$ for two loci associations was calculated according to Mattiuz et al. [12]. The relative linkage disequilibrium $\left(\Delta_{\mathrm{r}}\right)$, which gives an indication of the strength of associations between pairs of sequences, was calculated for each pair using $\Delta_{\max }$ and the observed two-locus haplotype frequency [13]. The differences 
Table I: Comparison of the KIR gene frequency observed in the Italian multicentric study with Caucasian and non-Caucasian populations.

\begin{tabular}{|c|c|c|c|c|c|c|c|c|c|c|c|c|c|c|c|}
\hline KIR gene & $\begin{array}{c}\text { Italian Study } \\
\text { (n.217) (\%) }\end{array}$ & $\begin{array}{l}\text { Australian } \\
\text { Caucasian } \\
\text { Witt et al } \\
\text { (n. } 145)(\%)\end{array}$ & $\begin{array}{l}\text { Irish Crum et } \\
\text { al. (n.90) (\%) }\end{array}$ & $\begin{array}{l}\text { Germany } \\
\text { Uhrber et al. } \\
\text { (n.120) (\%) }\end{array}$ & $\begin{array}{l}\text { German Becher } \\
\text { et al. }(\mathrm{n} .90)(\%)\end{array}$ & $\begin{array}{l}\text { Greek Niokou } \\
\text { et al. (n.233) (\%) }\end{array}$ & $\begin{array}{l}\text { North Indian } \\
\text { Rajalingam et al. } \\
\text { (n.72) (\%) }\end{array}$ & $\begin{array}{l}\text { Vietnamese } \\
\text { Toneva et al. } \\
(\text { (n.59) (\%) }\end{array}$ & $\begin{array}{c}\text { Australian } \\
\text { Aborigine } \\
\text { Toneva et al. } \\
\text { (n.67) (\%) }\end{array}$ & $\begin{array}{l}\text { Thailandia } \\
\text { Norman et al. } \\
\text { (n.119) (\%) }\end{array}$ & $\begin{array}{c}\text { Palestinian } \\
\text { Norman et al. } \\
\text { (n.105) (\%) }\end{array}$ & $\begin{array}{c}\text { Afro } \\
\text { Caribbean } \\
\text { Cook et al. } \\
\text { (n.54) (\%) }\end{array}$ & $\begin{array}{l}\text { Asian Cook et } \\
\text { al. (n.35) (\%) }\end{array}$ & $\begin{array}{l}\text { Chinese Han } \\
\text { Jiang et al. } \\
\text { (n. 104) (\%) }\end{array}$ & $\begin{array}{c}\text { Japanese } \\
\text { Yawata etal. } \\
(\text { (n.41) (\%) }\end{array}$ \\
\hline $2 D L I$ & 95 & 96 & $\$ 84 P 0.009$ & 93 & 87 & 89 & 91 & 98 & $\$ 72 P 0.0001$ & 97 & $\S 83 P 0.004$ & 90 & 86 & 99 & 100 \\
\hline $2 D L 2$ & 53 & $\begin{array}{c}\$ 31 \\
P 0.0001\end{array}$ & 50 & 56 & 50 & 50 & $79 P 0.0001$ & 37 & $78 \mathrm{PO} 0.003$ & 42 & 62 & 54 & 54 & 17 P0.000I & $\$ 17 P 0.0001$ \\
\hline $2 D L 3$ & 88 & 95 & 90 & 87 & $\$ 65 P 0.0001$ & 88 & 91 & 98 & $\$ 65 P 0.0001$ & 97 & 85 & 91 & 86 & 99 P0.0001 & 100 \\
\hline $2 D L 5 A$ & 33 & $\mathrm{nt}$ & $\mathrm{nt}$ & $\# 44$ & $\# 79$ & nt & $\mathrm{nt}$ & $\mathrm{nt}$ & $\mathrm{nt}$ & $\mathrm{nt}$ & $\mathrm{nt}$ & $\# 33$ & $\# 26$ & 31 & $\# 39$ \\
\hline $2 D L 5 B$ & 28 & nt & $\mathrm{Nt}$ & $\mathrm{nt}$ & $\mathrm{nt}$ & nt & $\mathrm{nt}$ & $\mathrm{nt}$ & $\mathrm{nt}$ & $\mathrm{nt}$ & $\mathrm{nt}$ & $\mathrm{nt}$ & $\mathrm{nt}$ & $6 P 0.0001$ & $\mathrm{nt}$ \\
\hline $2 \mathrm{DSI}$ & 36 & 51 & 56 & 37 & 39 & 43 & 54 & 38 & $82 P 0.0001$ & 42 & 44 & 17 & 49 & 34 & 34 \\
\hline $2 D S 2$ & 53 & 51 & 51 & 62 & 49 & 54 & 62 & 41 & $84 P 0.0001$ & 44 & 64 & 52 & 57 & $17 P 0.0001$ & $\$ 17 P 0.0001$ \\
\hline $2 D S 3$ & 33 & 28 & 27 & 28 & 22 & 37 & 43 & 31 & $81 P 0.0001$ & 25 & 37 & 24 & 29 & $12 P 0.0001$ & $\$ 17 P 0.0001$ \\
\hline $\begin{array}{l}2 \mathrm{DS} 4 \\
* 001- \\
* 002\end{array}$ & 33 & $\#$ nt & $\#$ nt & $\#$ nt & $\#$ nt & $\#$ nt & $\#$ nt & $\# \mathrm{nt}$ & $\#$ nt & $\#$ nt & $\# \mathrm{nt}$ & $\#$ nt & $\# \mathrm{nt}$ & $80 P 0.0001$ & $\#$ nt \\
\hline $\begin{array}{l}2 D S 4 * \\
003\end{array}$ & 89 & 92 & 96 & 98 & 96 & 88 & 80 & 87 & 81 & 87 & 88 & 78 & 83 & $42 P 0.0001$ & $96 \mathrm{P0.0001}$ \\
\hline 2DS5 & 28 & nt & 35 & 26 & 27 & 21 & $47 P 0.002$ & $\mathrm{nt}$ & $\mathrm{nt}$ & 23 & 27 & 30 & $51 P 0.008$ & 23 & 28 \\
\hline $3 D L I$ & 96 & 96 & 92 & 96 & $\$ 87 P 0.0003$ & 90 & 91 & 89 & $\S 57$ P0.000I & 93 & 88 & 98 & 91 & 94 & 97 \\
\hline $3 D S I$ & 35 & $\mathrm{nt}$ & $\mathrm{Nt}$ & $\mathrm{nt}$ & 36 & 46 & 39 & 41 & 78 P0.000I & 44 & 39 & 17 & 40 & 32 & 33 \\
\hline
\end{tabular}

With the exception of the Chinese Han population, the primers used were not the same as in the Italian study and hence cannot afford a real comparison. However, any higher percentages of detection are significant. \# It should be noted that values given for $2 \mathrm{DL} 5$ and $2 \mathrm{DS} 4 * 003$ may contain $2 \mathrm{DL} 5 \mathrm{~B}$ and $2 \mathrm{DS} 4 * 00 \mathrm{I} / 002$ positivities where the latter alleles are reported as not-tested (nt). 
Table 2: Linkage disequilibrium values of KIR associations.

\begin{tabular}{|c|c|c|c|c|c|c|c|c|c|c|c|c|c|}
\hline & & 2DL2 & $2 \mathrm{DL} 3$ & 2DL5A & 2DL5B & $2 \mathrm{DSI}$ & 2DS2 & $2 \mathrm{DS} 3$ & $\begin{array}{c}\text { 2DS4* } \\
001-002\end{array}$ & $\begin{array}{c}\text { 2DS4* } \\
003\end{array}$ & $2 \mathrm{DS} 5$ & $3 \mathrm{DLI}$ & 3DSI \\
\hline 2 & $\Delta$ & -0.004 & 0.097 & 0.025 & 0.019 & 0.01 & 0.004 & 0.036 & 0.03 & 0.001 & 0.006 & 0.031 & 0.003 \\
\hline $\mathrm{D}$ & $\mathrm{R}$ & -0.055 & 0.69 & 0.597 & 0.586 & 0.241 & 0.055 & 0.924 & 0.761 & 0.011 & 0.193 & 0.201 & 0.064 \\
\hline $\mathrm{L}$ & $\mathrm{H}$ & 0.246 & 0.623 & 0.168 & 0.14 & 0.15 & 0.246 & 0.18 & 0.117 & 0.539 & 0.115 & 0.685 & 0.159 \\
\hline I & $P$ & & $<0.0001$ & & & & & $<0.05$ & & & & & \\
\hline 2 & $\Delta$ & & -0.137 & 0.014 & 0.101 & 0.013 & 0.205 & 0.099 & 0.012 & -0.031 & 0.003 & -0.005 & 0.025 \\
\hline D & $\mathrm{R}$ & & -1.186 & 0.106 & 0.990 & 0.096 & 0.944 & 0.811 & 0.1 & 0.295 & 0.026 & 0.087 & 0.196 \\
\hline $\mathrm{L}$ & $\mathrm{H}$ & & 0.071 & 0.07 & 0.149 & 0.077 & 0.304 & 0.156 & 0.071 & 0.181 & 0.05 & 0.252 & 0.087 \\
\hline 2 & $P$ & & $<0.0001$ & & $<0.0001$ & & $<0.0001$ & $<0.0001$ & & & & & \\
\hline 2 & $\Delta$ & & & 0.001 & -0.096 & 0.001 & -0.115 & -0.086 & -0.022 & 0.025 & -0.016 & 0.007 & -0.028 \\
\hline D & $\mathrm{R}$ & & & 0.022 & -1.774 & 0.012 & -1 & -1.333 & -0.347 & 0.120 & -0.301 & 0.054 & -0.407 \\
\hline $\mathrm{L}$ & $\mathrm{H}$ & & & 0.12 & 0.005 & 0.135 & 0.092 & 0.032 & 0.1 & $0.47 \mid$ & 0.084 & 0.549 & 0.102 \\
\hline 3 & $P$ & & & & $<0.0001$ & & $<0.001$ & $<0.001$ & & & & & \\
\hline 2 & $\Delta$ & & & & 0.02 & 0.135 & 0.022 & 0.04 & -0.05 & -0.052 & 0.108 & -0.051 & 0.133 \\
\hline D & $\mathrm{R}$ & & & & 0.162 & 0.886 & 0.167 & 0.269 & $-0.34 I$ & -0.835 & 0.887 & -1.35 & 0.863 \\
\hline L & $\mathrm{H}$ & & & & 0.047 & 0.171 & 0.078 & 0.071 & -0.016 & 0.069 & 0.135 & 0.096 & 0.168 \\
\hline $5 \mathrm{~A}$ & $P$ & & & & & $<0.0001$ & & $<0.001$ & $<0.0001$ & $<0.05$ & & & \\
\hline 2 & $\Delta$ & & & & & 0.019 & 0.104 & 0.119 & -0.01 & -0.022 & 0.01 & -0.035 & 0.018 \\
\hline D & $\mathrm{R}$ & & & & & 0.162 & 1.022 & 0.969 & -0.078 & -0.445 & 0.071 & -1.157 & 0.147 \\
\hline $\mathrm{L}$ & $\mathrm{H}$ & & & & & 0.050 & 0.152 & 0.146 & 0.02 & 0.08 & 0.032 & 0.1 & 0.048 \\
\hline $5 B$ & $P$ & & & & & & $<0.0001$ & $<0.0001$ & & & & & \\
\hline 2 & $\Delta$ & & & & & & 0.021 & 0.028 & -0.05 & -0.08 & 0.115 & -0.047 & 0.127 \\
\hline D & $\mathrm{R}$ & & & & & & 0.156 & 0.195 & -0.348 & -1.212 & 0.962 & -1.18 & 0.839 \\
\hline S & $\mathrm{H}$ & & & & & & 0.085 & 0.064 & 0.012 & 0.056 & 0.146 & 0.119 & 0.167 \\
\hline I & $P$ & & & & & & & $<0.05$ & $<0.0001$ & $<0.05$ & $<0.0001$ & & $<0.0001$ \\
\hline 2 & $\Delta$ & & & & & & & 0.106 & 0.016 & -0.02 & 0.01 & -0.005 & 0.025 \\
\hline D & $\mathrm{R}$ & & & & & & & 0.868 & 0.132 & 0.185 & 0.103 & -0.087 & 0.196 \\
\hline$S$ & $\mathrm{H}$ & & & & & & & 0.163 & & & & & \\
\hline 2 & $P$ & & & & & & & $<0.0001$ & 0.075 & 0.192 & 0.058 & 0.252 & 0.087 \\
\hline 2 & $\Delta$ & & & & & & & & -0.011 & -0.032 & 0.003 & -0.051 & 0.04 \\
\hline D & $\mathrm{R}$ & & & & & & & & -0.076 & -0.537 & 0.028 & -1.425 & 0.275 \\
\hline$S$ & $\mathrm{H}$ & & & & & & & & 0.022 & 0.09 & 0.031 & 0.096 & 0.075 \\
\hline 3 & $P$ & & & & & & & & & & & & $<0.001$ \\
\hline 2 & $\Delta$ & & & & & & & & & -0.107 & -0.039 & 0.0003 & -0.039 \\
\hline D & $\mathrm{R}$ & & & & & & & & & $-|.81|$ & -0.321 & 0.009 & -0.271 \\
\hline S & $\mathrm{H}$ & & & & & & & & & 0.019 & 0.011 & 0.155 & -0.003 \\
\hline $\begin{array}{l}4 * 001 \\
* 002\end{array}$ & $P$ & & & & & & & & & $<0.0001$ & $<0.01$ & & $<0.05$ \\
\hline 2 & $\Delta$ & & & & & & & & & & -0.061 & 0.108 & -0.07 \\
\hline D & $\mathrm{R}$ & & & & & & & & & & -1.24 & 0.804 & -1.108 \\
\hline S & $\mathrm{H}$ & & & & & & & & & & $0.04 I$ & 0.661 & 0.063 \\
\hline $4 * 003$ & $P$ & & & & & & & & & & $<0.05$ & $<0.000$ & $<0.05$ \\
\hline 2 & $\Delta$ & & & & & & & & & & & -0.056 & 0.105 \\
\hline D & $\mathrm{R}$ & & & & & & & & & & & -1.876 & 0.862 \\
\hline$S$ & $\mathrm{H}$ & & & & & & & & & & & 0.068 & 0.135 \\
\hline 5 & $P$ & & & & & & & & & & & $<0.05$ & $<0.0001$ \\
\hline 3 & $\Delta$ & & & & & & & & & & & & -0.076 \\
\hline
\end{tabular}


Table 2: Linkage disequilibrium values of KIR associations. (Continued)

\begin{tabular}{lll}
\hline$D$ & $R$ & -2.01 \\
$L$ & $H$ & 0.085 \\
$\mathrm{I}$ & $\mathrm{P}$ & $<0.05$ \\
\hline
\end{tabular}

$\Delta=$ linkage disequilibrium parameters $; R=$ relative linkage disequilibrium; $H=$ estimated two locus haplotype frequency; $P=P$ value

between the observed and expected haplotype frequencies were compared by Yates $\chi^{2}$ contingency tables.

\section{Results}

All participating laboratories had the same typing of the two shared DNA. No ambiguities were observed and no false or negative results were described by the laboratories.

The frequencies of the KIR genes are compared to other Caucasian and non-Caucasian populations in table 1.

The KIR2DL4, KIR3DL2, KIR3DL3 framework genes were found in all individuals whereas all other inhibitory and non-inhibitory genes were present in a varying percentage of individuals.

KIR2DL1 gene was present in 95\% of the Italian Caucasian population, while in the Australian Aborigine, Palestinian and in Irish populations it is found at the lowest frequency $(72,83$ and 84 percent, respectively) $[8,14,15]$. The frequency of KIR2DL2 was $53 \%$ in the Italian population which was higher than in the Australian Caucasian, Chinese Han and Japanese but lower than the Australian Aborigine $(78 \%)$ and North Indian $(79 \%)$ populations [6,8,16-18]. KIR2DL3 and KIR3DL1 have a frequency similar to that observed in the Caucasian population, except for a German regional population described by Becker and in the Aborigine population which were both lower $[8,19,20]$; in Chinese Han and Japanese populations the frequency was higher $[17,18]$.

The non-inhibitory KIR2DS1, KIR2DS2, KIR2DS3 genes have a frequency lower than observed in the Australian Aborigine population $(\mathrm{p}<0.005)$ but higher than in the
Chinese Han and Japanese population, though only for KIR2DS2 and KIR2DS3 $[8,17,18]$.

KIR2DS4 gene was present in a high percentage in the Italian population; the expression of allele * 003 which identifies the gene variant was present in $89 \%$ of subjects studied, as compared to alleles ${ }^{*} 001$ and ${ }^{*} 002$, which are only represented in $33 \%$ of the population [21]. A reverse positivity of the alleles was observed to that of the Chinese Han population [17].

KIR2DS5 gene has a frequency similar to other Caucasian populations, but is lower than that observed in Asian populations, while KIR3DS1 has a frequency similar to other Caucasian and non-Caucasian populations except in the Aborigines in whom it is present in a double percentage $[7,8,16]$.

Linkage distribution (LD) and relative LD values show significant differences between individual KIR pairs (Table 2).

Among the main inhibitory KIRs, we showed a positive linkage disequilibrium between KIR2DL1 and KIR2DL3 whereas KIR2DL2 is in negative linkage with KIR2DL3. About the only non-inhibitory gene observed in genotype $1, K I R 2 D S 4^{*} 001 / 002$ is negatively linked with its variant KIR2DS $4 * 003$.

The main pairs of KIR genes that show a significant positive and negative linkage disequilibrium are summarized in table 3.

The KIR repertoire is substantially influenced by the polymorphic and polygenic nature of the KIR gene. In all, 65

Table 3: Pairs of KIR genes that show significant positive and negative linkage disequilibrium

\begin{tabular}{ll}
\hline Positive linkage disequilibrium & Negative linkage disequilibrium \\
\hline 2DLI-2DL3, 2DLI-2DS3 & $2 D L 2-2 D L 3$ \\
2DL2-2DL5B, 2DL2-2DS2, 2DL2-2DS3 & $2 D L 3-2 D L 5 A, 2 D L 3-2 D S 2,2 D L 2-2 D S 30$ \\
2DL5A-2DSI, 2DL5A-2DS3 & $2 D L 5 A-2 D S 4 * 00 I-02,2 D L 5 A-2 D S 4 * 003$ \\
2DL5B-2DS2, 2DL5B-2DS3 & $2 D S I-2 D S 4 * 00 I-002,2 D S I-2 D S 4 * 003$ \\
2DSI-2DS3, 2DSI-2DS5, 2DSI-3DSI & $2 D S 4 * 00 I-002-2 D S 4 * 003$, \\
2DS2-2DS3 & $2 D S 4 * 001-002-2 D S 5,2 D S 4 * 001-002-3 D S I$ \\
$2 D S 3-3 D S I$ & $2 D S 4 * 003-2 D S 5$ \\
$2 D S 4 * 003-3 D L I, 2 D S 4 * 003-3 D S I$ & $2 D S 5-3 D L I$ \\
$2 D S 5-3 D S I$ & $3 D L I-3 D S I$ \\
\hline
\end{tabular}


Table 4: Distribution of the main phenotypes observed in the Italian population. The nomenclature system from Uhrberg is used for describing the patterns (5). Each genotype is also shown in the different patterns due to the distribution of KIR2DS4 alleles and the KIR2DL5 variants.

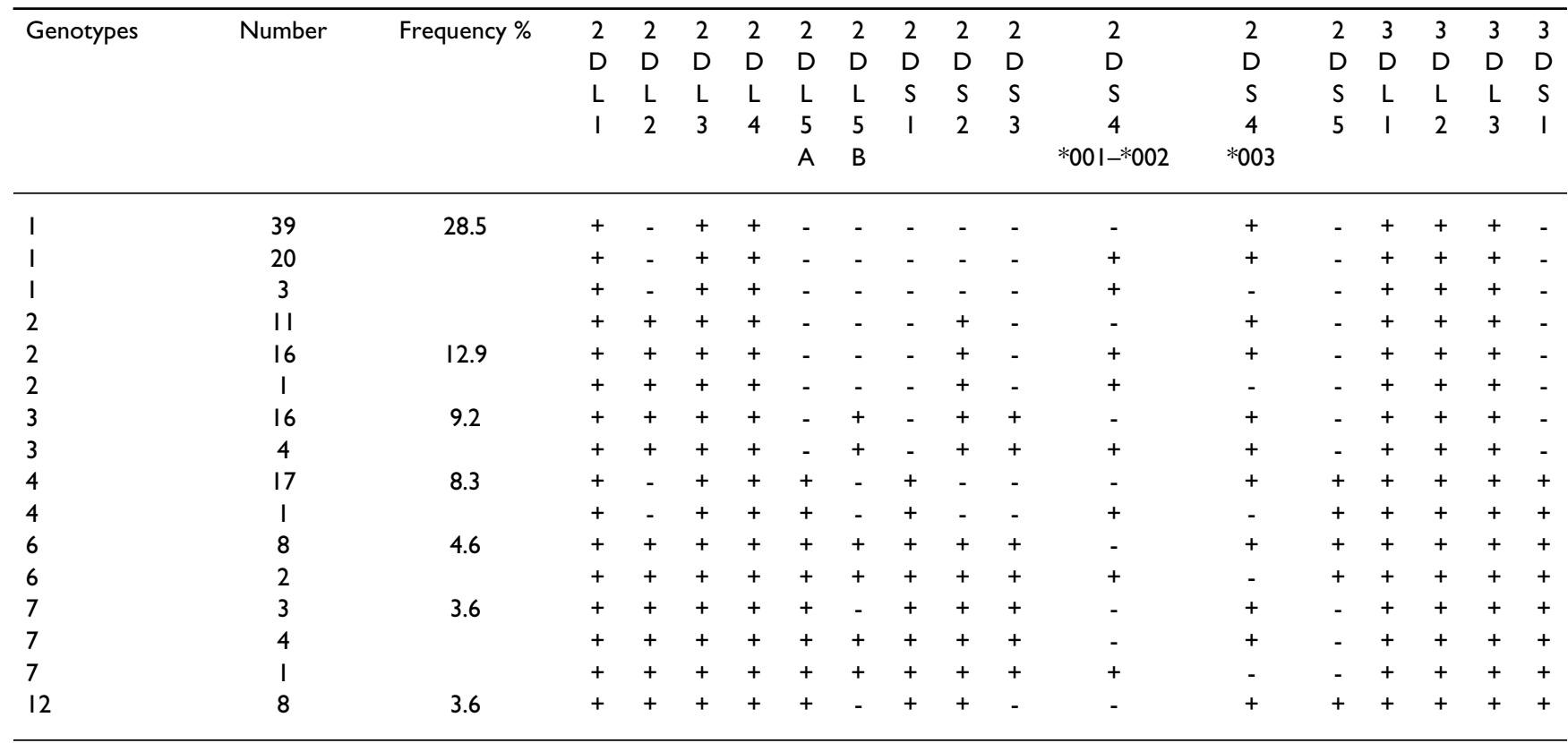

different profiles were found in the Italian population without pseudogenes and 74 if we include KIR2DP1 and KIR3DP1 among the 217 samples tested.

Genotypes containing between 6 and 15 genes are included. Genotypes with seven and eleven genes are the most represented in the study population, respectively in 44 and 45 cases.

Following the Uhrberg classification, out of the 65 genotypes identified the most frequent are genotypes 1, 2, 3, 4, $6,7,12,5$ and 9 with a frequency of $28.5 \%, 12.9 \%, 9.2 \%$, $8.3 \%, 4.6 \%, 3.6 \%, 3.6 \%, 2.3 \%$ and $1.3 \%$ respectively (Table 4) [4].

In particular, genotype 1 , observed in 62 samples with a frequency of $28.5 \%$, closely resembles that observed in the other Caucasian, Palestinian and Thai populations, but not in the Indian and Aborigine populations, which have a frequency of $5.6 \%$ and $1.7 \%$, respectively $[5,6,8,15,16]$. In this genotype the expression of KIR2DS4 is related to the homozygous allele ${ }^{*} 003$ in 39 out of 62 and in 20 out of 62 samples in heterozygous combinations with allele ${ }^{*} 001 /{ }^{*} 002$.

Genotype 2 was present in 28 people with a frequency of $12.9 \%$; it includes the inhibitory gene KIR2DL2 and has a frequency higher than that observed in other Caucasian and non-Caucasian populations or in the Palestinian and Thai populations which have a similar frequency $[6,8,15]$.
In this case KIR2DS4*003 is in heterozygous and homozygous combinations in 11 and 16 out of 28 individuals, respectively.

Genotype 3 with a frequency of $9.2 \%$ (20 samples) always includes gene KIR2DL2 and has a frequency that is higher than the Australian Caucasian, Greek and German populations, while it has a similar percentage to that observed in another German study and in a Palestinian population study $[5,6,19]$. Genotypes included KIR2DL5 which is only positive in the variant KIR2DL5B, while KIR2DS4 is positive for the homozygous allele ${ }^{*} 003$ in 16 samples.

Genotype 4, observed in 18 people with a frequency of $8.3 \%$, is lower than that observed in Australian Caucasian and Irish populations but similar to that observed in other Caucasian and non-Caucasian studies $[6,8,14]$. In this genotype KIR2DL5 is always positive in the variant KIR2DL5A while KIR2DS4 is positive in homozygous combination for the allele * 003 in $80 \%$ of this genotype.

Genotype 6 includes all inhibitory and non-inhibitory genes and is present in 10 cases $(4.6 \%)$ somewhat similar to the position observed in the Caucasian and non-Caucasian populations but not in the Australian Aborigine [6]. In this genotype the two variants of KIR2DL5 are equally expressed while KIR2DS ${ }^{*} 003$ is present in 8 out of 10 cases. 
Genotype 7, which includes all inhibitory and non-inhibitory genes except KIR2DS5, has a frequency of $3.6 \%$ which is lower than has been observed in other Caucasian populations, similar to the finding in Palestinian and Thai studies and much lower than in the Australian Aborigine population $[6-8,15] . K I R 2 D L 5 A$ is positive in all samples and KIR $2 D L 5 B$ in about half. Allele KIR $2 D S 4^{*} 003$ is observed in 7 out of 8 samples.

Genotype 12 has a percentage of $3.6 \%$, similar to that observed in other Caucasian and non-Caucasian populations except in Australian Caucasians where it is higher [6]. In these 8 samples we only have positivity in genes KIR2DL5A and KIR2DS4*003.

Genotypes 5 and 9, which are characterized by positivity for KIR2DL1 and KIR2DL2 and negativity for KIR2DL3, have a frequency of $2.3 \%$ and $1.3 \%$ respectively.

The A putative homozygote haplotypes in the Italian population are the most prevalent (57\%) and the distribution of genotypes in terms of combination of haplotypes proves to be AA 28.5\%, AB 69.5\% and BB about 2\% [10].

Pseudogene typing shows a close correlation between KIR2DP1 and haplotype A while it is absent in haplotype $\mathrm{B}$. Haplotype A is also characterized by the presence in all samples of allele KIR3DP $1{ }^{*} 003$, while genotype $\mathrm{B}$ in our four samples only shows positivity for KIR3DP1*001/002 [21].

\section{Discussion}

In this work we evaluated the percentage of the population positive for each KIR gene as well as the KIR genotype frequency in a representative ethnic Italian group of 217 randomly selected unrelated healthy individuals from 22 immunogenetics laboratories, located in northern, central and southern regions of Italy.

All the participating laboratories studied the two shared DNA samples and the results showed typing consensus. Each KIR gene was detected by a single primer mix and no ambiguities were observed. Management of the new kit was acceptable by all laboratories.

The percentage of the population positive for a KIR gene was compared to other Caucasian and non-Caucasian populations [5-8,14-20]. While the differences in terms of low percentages observed in isolated genes could be connected with the primers that we used in typing, since these may have recognized alleles that were not evaluated in early published studies, the opposite should not apply: where older methods developed more positivity than ours (as with KIR2DL2 in the Australian Aborigine and North
Indian populations), our results must be taken as significant.

The three populations that show most markedly different patterns from ours are the Australian Aborigine, Chinese Han and Japanese, in particular for inhibitor genes KIR2DL2 and non inhibitor KIR2DS1, KIR2DS2, KIR2DS3, KIR3DS1, which have a significant difference from our Italian study, as indeed from other Caucasian population evaluations $[6,17,18]$.

For the Chinese Han population study the same primers were used as in our own and hence form a valid point of comparison. In particular, inhibitor genes such as KIR2DL2 and KIR2DL5B were found in an extremely low percentage, as was the non inhibitor gene KIR2DS3. KIR2DS4 alleles are especially interesting since the Chinese pattern is exactly the inverse of the Italian [17].

KIR2DL1 and KIR2DL3 are observed in high positive linkage disequilibrium as detected in other Caucasian and non-Caucasian populations and this datum further suggests a segregation of KIR region haplotypes into two groups distinguished by KIR2DL1/KIR2DL3 and $K I R 2 D L 2$, although the latter is claimed to have arisen as a recombination event between KIR2DL1 and KIR2DL3 [22].

A negative linkage disequilibrium was identified between KIR2DS $4^{*} 001 / 002$ and KIR2DS4*003, suggesting their alleles may not be identical, as already confirmed in other Caucasian and non-Caucasian populations [23].

The KIR repertoire is substantially influenced by the polymorphic and polygenic nature of the KIR gene. However, using primers to identify the two variants of KIR2DL5 (2DL5A, 2DL5B) and the allele KIR2DS4*003, each genotype described by Uhrberg might be assigned to a haplotype with more than one combination $[4,23,24]$.

In this study we observed that genotype 1 is the most representative, as in other Caucasian populations, and our data are in agreement with other studies on Caucasian populations concerning the predominance of the haplotype A group over the haplotype B group [5]. This means that $28.5 \%$ of the Italian population have KIR2DS4 as the only activating gene. Bearing in mind the high percentage of individuals who have only the deleted form of KIR2DS4, this would lead to at least $18 \%$ of this population not having a functional activating receptor, provided that the assumption of the deleted form of KIR2DS4 not being expressed is correct [23].

Genotype 1 is also the most frequent in the Chinese Han non-Caucasian population but the percentage is higher 
than observed in our study ( $58.7 \%$ vs $28.5 \%$ ). In this genotype the distribution of the KIR2DS4 alleles has a completely contrary pattern to what we observed in our population, suggesting a different positivity of the alleles but also a different haplotype recombination in the populations [17]. The particular distribution of KIR genes could be due to a selection pressure, which would favour a particular combination of KIR genes, and this phenomenon could be explained by the linkage disequilibium observed.

The actual number of genotypes in the Italian study population is likely to be much lower higher than we surmised because the medium level of resolution was only studied for KIR2DL5 and KIR2DS4. Typings for the two groups, alleles KIR2DL5 and KIR2DS4, already show an increase in the variety of KIR gene profiles. Moreover the distribution of the patterns described should be revised because the analysis in which there was no or low discrimination of alleles will have overestimated the similarities and underestimated the differences between populations $[25,26]$.

Combinations of particular HLA-KIR genotypes have also been linked with susceptibility to autoimmune diseases such as psoriatic arthritis and type I diabetes, just as several genetic studies have revealed an influence of HLA-KIR gene interactions on disease outcome.

Interactions between HLA-Bw4 and KIR3DS1 gene have been observed in cases of delayed progression to AIDS in HIV patients, while the homozygosity of both HLA-C1 and KIR2DL3 is associated with resolution of hepatitis $\mathrm{C}$ virus infection. Understanding the basis for these observed genetic associations is complicated by the extensive polymorphism found among KIR haplotypes, which differ not only in nucleotide sequence but also in gene content [27].

In having established the percentage of the population positive for a KIR gene and the distribution of KIR genotyping, the present study may serve as a reference for other studies of genetic associations between KIR genes and specific diseases.

Recently several reports have described a role for KIR genes in bone marrow transplantation. At present the approach to identification of NK alloreactive donors in haploidentical bone marrow transplants has been based on KIR ligand incompatibility [11]. However this incompatibility has also been shown in HLA-identical sibling transplantation [28]. Therefore the availability of a simple, reproducible molecular biology test such as we have used in this study to type the KIR genes could become part of donor evaluation and selection, since it directly identi- fies the presence or absence of a given KIR gene in the donor. One important example of this is the lack of the KIR3DL1 gene for HLA-Bw4 inhibitory receptors, which immediately excludes about $4 \%$ of potential donors.

In broad conclusion, our study shows that the Italian population possesses the general KIR gene features reported in other Caucasian and non-Caucasian populations, but the discrepancies in the case of certain genes confirm the polymorphic and polygenic nature of the KIR genes in the population.

\section{Abbreviations}

KIR: Killer cell immunoglobulin-like receptors

\section{HLA: Human Leukocyte Antigen}

PCR-SSP: polymerase chain reaction sequence specific primer

\section{Authors' contributions}

$\mathrm{AB}$ and MT organized the collaborative study, carried out the molecular genetic study and drafted the manuscript; MCC and MM carried out the molecular genetic study and helped to draft the manuscript; CC, AC, EC, ED, SF, AMI, CL, AM, MM, LM, IM, LM, VM, SN, GO, DP, GR, CT and SV carried out the molecular genetic study, while MA and RC helped to draft the manuscript.

\section{Acknowledgements}

Italian KIR Collaborative AIBT Group Laboratories: Genetic Unit University of Pavia, Transfusion Service S. Matteo Hospital of Pavia, Genetic Unit University of Cagliari, Immunogenetic IBMDR Galliera Hospital of Genova, Transfusion Service Federico II Hospital of Napoli Transplant Immunology San Giovanni Battista-Molinette Hospital of Torino, Transplant Immunology Maggiore Hospital of Milano, Transfusion Service Istituto Nazionale Tumori of Milano, Immunology Service Spedali Civili of Brescia, Immunogenetic S. Camillo-Forlanini Hospital of Rome, Transfusion Service Cisanello Hospital of Pisa, Transfusion Service S. Gerardo Hospital of Monza, Transfusion Service SS. Antonio e Biagio Hospital of Alessandria, Transfusion Service S. Maria Misericordia Hospital of Udine, Immunogenetic Muraglia Hospital of Pesaro, Immunogenetic CNR of Roma, Immunogenetic CNR of L'Aquila, Immunogenetic B.M.M. Hospital of Reggio Calabria, Transfusion Service S. Bortolo Hospital of Vicenza, Immunogenetic Cattinata Hospital of Trieste.

\section{References}

I. Moretta A, Sivori S, Vitali M, Pende D, Morelli L, Augugliaro R, Bottino C, Moretta L: Existence of both inhibitory (p58) and activating (p50) receptors for HLA-C molecules in human natural killer cells. J Exp Med 1995, I 82:875-884.

2. Martin Am, Freitas EM, Witt CS, Christiansen FT: The genomic organization and evolution of the natural killer immunoglobulin-like receptor (KIR) gene cluster. Immunogenetics 2000, 5 I:268-80.

3. Selvakumar A, Steffens U, Dupont B: Polymorphism and domain variability of human killer cell inhibitory receptors. Immunol Rev 1997, 155:183-196.

4. Uhrberg M, Valiante NM, Shum BP, Shilling HG, Lienert-Weidenbach K, Corliss B, Tyan D, Lanier L, Parham P: Human diversity in killer cell inhibitory receptor genes. Immunity 1997, 7:753-763. 
5. Uhrberg M, Parham P, Wernet P: Definition of gene content for nine common group $B$ haplotypes of the Caucasoid population: KIR haplotypes contain between seven and eleven KIR genes. Immunogenetics 2002, 54:22I-229.

6. Witt CS, Dewing C, Sayer DC, Uhrberg M, Parham P, Christiansen FT: Population frequencies and putative haplotypes of the killer cell immunoglobulin-like receptor sequences and evidence for recombination. Transplantation 1999, 68: 1784-1789.

7. Cook MA, Moss PAH, Briggs DC: The distribution of $\mathbf{1 3}$ killercell immunoglobulin-like receptor loci in UK blood donors from three ethnic groups. Eur J Immunogen 2003, 30:2 I3-22I.

8. Toneva M, Lepage v, Lafay G, Dulphy N, Busson M, Lester S, Vu-Trien A, Michaylova A, Naumova E, Mccluskey J, Charron D: Genomic diversity of natural killer cell recepetor genes in three populations. Tissue Antigens 200I, 57:358-362.

9. Shilling HG, Young N, Guethlein LA, Cheng NW, Gardiner CM, Tyan D, Parham P: Genetic control of human NK cell repertoire. J Immunol 2002, 169:239-247.

10. Hsu KC, Chida S, Geraghty DE, Dupont B: The killer cell immunoglobulin-like receptor (KIR) genomic region: gene-order, haplotypes and allelic polymorphism. Immunol Rev 2002, 190:40-52.

11. Ruggeri L, Capanni M, Urbani E, Perruccio K, Shlomchik WD, Tosti A, Posati S, Rogaia D, Frassoni F, Aversa F, Martelli MF, Velardi A: Effectiveness of donor natural killer cell alloreactivity in mismatched hematopoietic transplants. Science 2002, 295:2097-2100.

12. Mattiuz PL, Ihde D, Piazza A, Ceppellini R, Bodmer WF: New approaches to the population genetic and segregation analysis of the HLA system. In Histocompatibility testing Edited by: Terasaky PI. Munskaard Copenhagen; 1970:193-205.

13. Bauer MP, Danilovs JA: Population analysis of HLA-A,B,C,DR and other genetic markers. In Histocompatibility testing Edited by: Terasaky PI. UCLA Tisue typing laboratory, Los Angeles; 1980:955-993.

14. Crum KA, Logue SE, Curran MD, Middleton D: Development of a PCR-SSOP approach capable of defining the natural killer cell inhibitory receptor (KIR) gene sequence repertoires. Tissue Antigens 2000, 56:313-326.

15. Norman PJ, Stephens HAF, Verity DH, Chandanayingyoug D, Vaughan RW: Distribution of natural killer cell immunoglobulin-like receptor sequences in three ethnic groups. Immunogenetics 200I, 52:195-205.

16. Rajalingam R, Krausa P, Shilling HG, Stein JB, Balamurugan A, McGinnis MD, Cheng NW, Mehra N, Parham P: Distinctive KIR and HLA diversity in a panel of north Indian Hindus. Immunogenetics 2002, 53:1009-1019.

17. Jiang K, Zhu FM, Lv QF, Yan LX: Distribution of killer cell immunoglobulin-like receptor genes in the Chinese Han population. Tissue Antigens 2004, 65:556-563.

18. Yawata M, Yawata N, McQueen KL, Cheng NW, Guethlein LA, Rajaalingam R, Shilling HG, Parham P: Predominance of group A KIR haplotypes in Japanese associated with diverse NK cell repertoires of KIR expression. Immunogenetics 2002, 54:543-550.

19. Becker S, Tonn T, Fussel T, Uhrberg M, Bogdanow M, Seifred E, Seidl C: Assessment of Killer Cell Immunoglobulin-like receptor expression and corresponding HLA class I phenotypes demonstrates heterogeneous KIR expression independent of anticipated HLA class I ligands. Human Immunol 2003, 64:183-193.

20. Niokou D, Spyropoulou-Vlachou M, Darlamitsou A, StavropoulosGiokas C: Distribution of killer cell immunoglobulin-like receptors in the Greek population. Human Immunol 2003, 64: $1167-1176$

21. Bradshaw D, Schamel CM, Posch P, Steiner NK, Hurely CK: Development of informatics tools for complex gene systems: Killer-cell immunoglobulin-like receptor genes. Tissue Antigens 2003, 6 I:II8-135.

22. Wilson MJ, Torkar M, Haude A, Milne S, Sheer D, Beck S, Trowsdale J: Plasticity in the organization and sequences of human KIR/ ILT gene families. Proc Natl Acad SCI USA 2000, 97:4778-4783.

23. Maxwell LD, Wallace A, Middleton D, Curran MD: A common KIR2DS4 deletion variant in the human that predicts a soluble KIR molecule analogous to the KIRID observed in the rhesus monkey. Tissue Antigens 2002, 60:254-258.
24. Gomez-Lozano N, Gardiner CM, Parham P, Vilches C: Some human KIR haplotypes contain two KIR2DL5 genes: KIR2DL5A and KIR2DL5B. Immunogenetics 2002, 54:3|4-3I9.

25. Marsh SGE, Parham P, Dupont B, Geraghty DE, Trwsdale J, Middleton D, Vilches C, Carrington M, Witt C, Guethlein LA, Shilling H, Garcia CA, Hsu KC, Wain H: Killer-cell immunoglobulin-like receptor (KIR) nomenclature report, 2002. Tissue Antigens 2003, 62:79-86.

26. Gomez-Lozano N, Vilches C: Genotyping of human killer-cell immunoglobulin-like receptor genes by polymerase chain reaction with sequence-specific primers: an update. Tissue Antigens 2000, 19:184-193.

27. Rajagopalan S, Long EO: Understanding how combinations of HLA and KIR genes influence disease. J Exp Med 2005, 20I:I025-1029.

28. Hsu KC, Keever-Taylor CA, Wilton A, Pinto C, Heller G, Arkun K, O'Reilly RJ, Horowitz MM, Dupont B: Improved outcome in HLA-identical sibling hematopoietic stem-cell transplantation for acute myelogenous leukemia predicted by KIR and HLA genotypes. Blood 2005, 105:4878-4884.

Publish with Bio Med Central and every scientist can read your work free of charge

"BioMed Central will be the most significant development for disseminating the results of biomedical research in our lifetime. "

Sir Paul Nurse, Cancer Research UK

Your research papers will be:

- available free of charge to the entire biomedical community

- peer reviewed and published immediately upon acceptance

- cited in PubMed and archived on PubMed Central

- yours - you keep the copyright 